\title{
The Effect of List-Group-Label Strategy on Students' Reading Interpretative Comprehension
}

\author{
Pengaruh Strategi List-Group-Label tentang Interpretasi Bacaan Siswa Pemahaman
}

\author{
Afore Tahir Harefa \\ Institut Keguruan dan Ilmu Pendidikan (IKIP) Gunungsitoli \\ aforetahirharefa@gmail.com
}

\begin{abstract}
Reading in the level interpretative comprehension is an activity of the students to respond, to get information and meaning by making inferences and reading between the line from the reading text. This study revealed the problem namely: the students are not able to identify the content words such as verb, noun, adjective, and adverb from the text, the students less of vocabulary, the students are not able to answer the comprehension question from the text by applied List-Group-Label Strategy in teaching and learning reading process with narrative text. The purpose of the research is to find out whether there is or there is no significant effect of List-Group-Label Strategy on Students' Reading Comprehension of Narrative Text The research has conducted by using quantitative research with the experimental research and the design of the research was quasi experimental design. The population of the research are the students of Junior High and the sample are the Eighth Grade that with of two classes as experimental class and as control class. Each class consisted of 30 students. The researcher has selected sample by using saturation sampling technique. The instrument used in collecting the data is written test. Afterward, the researcher gives pretest and posttest to the experimental group and control group to find the normality of the data and the homogeneity of the sample. After conducting the research, the researcher analyzed the data and resulted the testing of hypothesis, $t$-count was 5.067 and t-table was 2.002. Whereas t-count (5.067) >t-table (2.002), it can concluded that Ho is rejected and Ha is accepted. In conclusion, there is a significant effect of list-group-label strategy on students' reading comprehension of narrative text.
\end{abstract}

Keywords: reading Comprehension, list-group-label strategy, experimental research

\begin{abstract}
Abstrak
Membaca pada tingkatan pemahaman interpretatif adalah kegiatan siswa untuk merespons, mendapatkan informasi dan makna dengan membuat kesimpulan dan membaca yang tersirat dari teks bacaan. Penelitian ini mengungkapkan masalah yaitu: siswa tidak mampu mengidentifikasi kata-kata konten seperti verb, noun, adjective, dan adverb dari teks, siswa kurang kosakata, siswa tidak mampu menjawab pertanyaan pemahaman dari teks dengan menerapkan strategi List-Group-Label dalam proses belajar mengajar membaca teks naratif. Tujuan dari penelitian ini adalah untuk mengetahui ada atau tidaknya pengaruh yang signifikan strategi List-Group-Label terhadap pemahaman membaca siswa pada teks narasi. Penelitian ini adalah desain quasi eksperimen. Populasi dalam penelitian ini adalah siswa SMP dan sampelnya adalah siswa kelas VIII yang terdiri dari dua kelas sebagai kelas eksperimen dan sebagai kelas kontrol. Setiap kelas terdiri dari 30 siswa. Peneliti memilih sampel dengan menggunakan teknik sampling jenuh. Instrumen yang digunakan dalam pengumpulan data adalah tes tertulis. Selanjutnya peneliti memberikan pretest dan posttest pada kelompok eksperimen dan kelompok kontrol untuk mengetahui normalitas data dan homogenitas sampel. Setelah
\end{abstract}


melakukan penelitian, peneliti menganalisis data dan menghasilkan pengujian hipotesis, t-hitung sebesar 5,067 dan t-tabel sebesar 2,002. Sedangkan t-hitung $(5,067)>$ t-tabel $(2,002)$, dapat disimpulkan bahwa $\mathrm{Ho}$ ditolak dan $\mathrm{Ha}$ diterima. Kesimpulannya, ada pengaruh yang signifikan dari strategi List-Group-Label terhadap pemahaman membaca Siswa pada teks narasi.

Kata kunci: membaca pemahaman, list-group-label, penelitian eksperimen

\section{INTRODUCTION}

English teacher frequently disregard the significance of reading in the classroom. Though, student need reading skill to get data from magazines, novels, essays, books, and internet. In this manner, the requirement for reading and taking out the data from different text above seems to be extremely important. Pang, et al., in Andini (2019:33) state reading is a phase where students can get information and knowledge, and the ability to read becomes a window to the world and students' knowledge. reading is a stage where students can get data and information, and the capacity to read turns into a window to the world and students' information. Many people can read, however not all can get the meaning to what they read. In conclusion, reading is the ability to gain and gather meaning and information from the text that can be used to develop their knowledge. It implies that, reading is a sort of correspondence between at least two individuals, for example, the writer can impart the data to the readers then the readers are speaking with the writer of the reading material to get the information or knowledge.

Reading and comprehension should be one action which includes one another. According to Pang, et al., (2011:14) "comprehension is the most common way of getting meaning from associated text." In comprehending, the readers effectively utilize their deduction to draw in with the text to construct the meaning. In this way, reading comprehension is the capacity in building meaning and comprehension about the data that introduced in a reading. It supported by Grabe and Stoller (2011:11) affirm, "Reading for general perception is, in its most clear sense, the capacity to comprehend data in a text and decipher it fittingly". Nonetheless, comprehension ability is significantly more perplexing than this definition. As indicated by Snow in Suryani (2017:41) states, reading comprehension is the course of at the same time removing and developing through cooperation and inclusion with composed language. Accordingly, it tends to be inferred that reading comprehension is the method involved with getting texts, and to comprehend the written material readers should utilize assortment of abilities, for example, readers should have the option to make inferences, distinguish primary thoughts, and perceive subtleties from the selection.

However, based on researcher's pre-observation at Junior High School, was found some factors that makes students difficult to comprehend the text and less of ability in reading comprehension. First, they read gradually and word by word. They do not read the words in their gathering; therefore, the lost the meaning of the sentences and they can not get the thought or data brought of the sentence. So, when the teacher gives some questions from a reading text, the students can not answer the question. Second, they have lack of vocabulary and they do not have abilities to figure the meaning of specific words in the text. The latter is they don't have foundation information about the themes being discussed in the text. These factors make the indicators in the syllabus is not achieved.

Therefore, the researcher formulated some problems. First, the students were not able to identify the content words such as verb, noun, adjective, and adverb from the text. Second, the

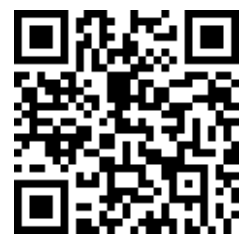

DOI PUBLIKASI https://doi.org/10.37010/int.v2i1 
students lack of vocabulary. The last, the students were not able to answer the comprehension question from the text.

Based on the problems above, the researcher applied List-Group-Label strategy to give the significant effect in ability reading comprehension. According to Allen in Sulaiman (2019:2) List-Group-Label is a brainstroming and sorting action that furnishes students with the chance to contemplate, discuss, classify, and name words related to an idea.

The impact positively by using this strategy is the students are able to answer the questions from the text. This procedure urges the students to improve their vocabulary and classification abilities, put together their verbal ideas, and help them in recalling and building up new vocabulary. (2001) calls attention to that speaking is intelligent and requires the capacity to collaborate in the administration of speaking turns. Moreover, it adds that the idea of the communicated in language measure implies that the grammar of the communicated in language varies altogether from the grammar of the composed language. As indicated by Harmer (2001:46), speaking happens when two individuals interface with each other. It is very evident that this is how they are doing say something or to convey messages and data. They have some correspondence purposes, and they browse their language store. Regarding to the explanation above, the researcher wants to conduct a research entitled: The Effect Of List-Group-Label Strategy On Students' Reading Interpretative Comprehension.

\section{RESEARCH METHOD}

In conducting the research, the researcher would conduct quantitative research method. According to Williams (2011:40), Quantitative research includes the assortment of information with the goal that data can be quantified and subjected to statistical treatment to help or invalidate elective information claims. The type of the research is experimental research. According to Sugiyono (2007:107) experimental research is defined as a method of research that is used to looking for certain influence toward the other on the controlled condition. There are several types of experimental research design, namely: true-experimental design, pre-experimental design, factorial design, and quasi-experimental design, (Sugiyono, 2011:110).

In this research, quasi-experimental design was used by the researcher. As indicated by Creswell (2009:158) says, in quasi-experiments, the agent utilizes control and test gatherings however doesn't haphazardly relegate members to bunch (for example they might be flawless gatherings accessible to the researcher)". Likewise, Sugiyono (2010:75) states that the principle normal for quasi-experiments is the advancement of true-experimental design, which has a benchmark group yet can't completely capacity to control outside factors that influence the execution of the analysis.

There are two types of quasi-experimental design, namely: time series design and nonequivalent control group design. In this research, the researcher utilized non-equivalent control group design. The non-equivalent control group design is a normally utilized plan. It contains an exploratory gathering and a benchmark group. The exploratory gathering gets treatment and control bunch do not get any treatment. Creswell (2009:160) states that in this plan, "the experimental group A and the experimental group B are chosen without irregular task. Moreover, as indicated by Sugiyono (2014: 116) states, in this design the trial gathering and control group are not picked arbitrarily. Both of gatherings stepped through a pre-exam and post-test, however just the trial bunch got the treatment. In this way, the researcher regulated a pre-test and a posttest for test and control gatherings, yet there was just one group (the experimental bunch) which instructed by utilizing List-Group-Label (LGL) system. 
Based on the previous explanation, the researcher used quasi-experimental design by using pretest and post-test which compares group design. The group would be divided into two groups as the sample of research, one group was experimental group and the other group was control group. In the experimental group, the researcher taught students by using List-GroupLabel Strategy while in control group, the researcher taught students by using Conventional Method. Quantitative data was acquired from the score of the student's speaking test. The test was given toward the finish of each cycle. The qualitative data was gathered through the observation result. It depicted the components that help the students' capacity to talk dependent on the outcome perception from the partner exercises both the students and the researcher itself.

groups as the sample of research, one group was experimental group and the other group was control group. In the experimental group, the researcher taught students by using List-GroupLabel Strategy while in control group, the researcher taught students by using Conventional Method. Quantitative data was gained from the score of the student's speaking test. The test was given at the end of every cycle. The qualitative data was collected through the result of observation. It described the factors that support the students' ability to speak based on the result observation from the collaborator activities both the students and the researcher itself.

\section{RESULT AND DISCUSSION}

\section{Result}

In the research, the researcher holds a pre-test and post-test both of Experimental and Control Group. Pre- test was used to examine the normality of data and the homogeneity of the sample, while posttest was used to examine the hypothesis of the research. Based on the students' mark, the researcher determined the mean score, standard deviation, and variance. The analysis of the mean, standard deviation, variance, normality, homogeneity, and hypothesis testing (t-test) in the pre-test and post-test are as follows.

Table 1. The Mean Score of Pre-Test and Post-Test in Experimental and Control Group

\begin{tabular}{llll}
\hline Group & $\mathrm{N}$ & Pre-Test & Post-Test \\
Control Group & 30 & 61.17 & 68.00 \\
Experimental Group & 30 & 63.50 & 79.67 \\
\hline
\end{tabular}

Table 2. The Standard Deviation of Pre-Test and Post-Test in Experimental and Control Group

\begin{tabular}{llll}
\hline Group & N & Pre-Test & Post-Test \\
Control Group & 30 & 10.78 & 10.05 \\
Experimental Group & 30 & 8.77 & 7.63 \\
\hline
\end{tabular}

Table 3. The Variance of Pre-Test and Post-Test in Experimental and Control Group

\begin{tabular}{llll} 
Group & N & Pre-Test & Post-Test \\
Control Group & 30 & 116.14 & 101 \\
Experimental Group & 30 & 76.92 & 58.22 \\
\hline
\end{tabular}


Table 4. The Normality Data of Pre-Test and Post-Test in Experimental and Control Group

\begin{tabular}{lccccc}
\hline \multirow{2}{*}{ Group } & $\mathbf{N}$ & \multicolumn{2}{c}{ Normality of Pre-Test } & \multicolumn{2}{c}{ Normality of Post-Test } \\
& & & & & \\
\cline { 3 - 6 } & & $\mathrm{L}_{\text {count }}$ & $\mathrm{L}_{\text {table }}$ & $\mathrm{L}_{\text {count }}$ & $\mathrm{L}_{\text {table }}$ \\
Control Group & 30 & 0.1157 & 0.161 & 0.1214 & 0.161 \\
Experimental Group & 30 & 0.1340 & 0.161 & 0.1173 & 0.161 \\
\hline
\end{tabular}

Table 5. The Homogeneity of Pre-Test and Post-Test in Experimental and Control Group

\begin{tabular}{llrlr}
\hline $\mathbf{N}$ & \multicolumn{2}{l}{ Homogeneity of Pre-Test } & \multicolumn{3}{l}{ Homogeneity of Post-Test } \\
\hline & $\mathrm{F}_{\text {count }}$ & $\mathrm{F}_{\text {table }}$ & $\mathrm{F}_{\text {count }}$ & $\mathrm{F}_{\text {table }}$ \\
$\mathbf{3 0}$ & 1.510 & 1.859 & 1.735 & 1.859 \\
\hline
\end{tabular}

Table 6. The Result of Hypothesis Testing

\begin{tabular}{lll}
\hline $\mathbf{t}_{\text {table }}=\mathbf{d f}=\mathbf{2}(\mathbf{n}-\mathbf{1})$ & $\mathbf{t}_{\text {count }}$ & Conclusion \\
\hline $\mathbf{2 . 0 0 2}$ & 5.067 & $\mathrm{t}_{\text {count }}(5.067)>\mathrm{t}_{\text {table }}(2.002)=$ \\
& Ha is accepted. \\
\hline
\end{tabular}

Based on appendix 15 , it shown that the table value of $\mathrm{t}$-table $\mathrm{df}=58$, in the significant level 5\% was $t_{\text {table }}=2.002$ and $t_{\text {count }}=5.067$. Since, $t_{\text {count }}(5.067)>t_{\text {table }}(2.002)$ it can be concluded that $\mathrm{Ho}$ is rejected and $\mathrm{Ha}$ is accepted. So, based on the testing hypothesis, it can be stated that there is any significant effect of List-Group-Label Strategy on Students' Reading Comprehension.

\section{Discussion}

Based on result of examining hypothesis, it proves that there is a significant effect of List-Group-Label Strategy on students' reading comprehension of narrative text. List-GroupLabel strategy helps students to identify what they know about the text and the words related to the topic. So, all the words they know from the text by using List-Group-Label strategy, they can use to comprehend the narrative text with answer some question related to the text.

In conducting this research, the researcher applied List-Group-Label Strategy. Before the researcher applied the strategy, the researcher gave pre-test to both of groups. Based on the data analysis of the students' ability in reading comprehension, it has indicated that the result of control group was enough and experimental group was enough. After calculating the score, the students' mean score of pre-test in control group was 61.17 and classified enough level. While, the mean score of pre-test in experimental group was 63.50 and classified enough level. Reflecting to the pre-test result, the researcher identified some roots of the students' problem in reading comprehension. After the researcher gave pre-test, the researcher treated the both of group with teaching them with different teaching strategy. The researcher taught the students of experimental group by using List-Group-Label strategy, while the students of control group taught through Conventional Teaching Method. After the researcher has applied the method, the 
researcher gave post-test both of group to find out whether there is a significant effect of this strategy on students' ability in reading comprehension.

Regarding to the analysis and interpretation of research findings, the three of identification of the problems in the research has been affected. First, the students were not able to identify the content words such as verb, noun, adjective, and adverb from the text. According to Burgmeier, Eldred, and Zimmermen in Wahyuni (2019:15) the difficulty of reading comprehension can be divide understanding words, putting words into sentence, using word in context and the last identify the content word. The content word related to reading comprehension especially languages features of narrative text. Second, the students lacked of vocabulary. Seyabi and Tuzlukova (2015:4) state that lack of vocabulary affect reading comprehension of the students. The limited vocabulary that students have makes them not understand the meaning of words, so they find it difficult to understand the whole text. And the last, the students were not able to answer the comprehension question from the text. One of the problem that makes students less ability to comprehend the reading text is the students are not able to answer the question from the text. According to Abbas (2016:234), asking appropriate questions permits successful readers to concentrate on the most important information of a text. Students' inability to answer questions affects students' reading comprehension because answering questions from the reading text correctly is one measure of understanding a text.

To find out the effect of problems above, the researcher applied List-Group-Label Strategy. Previously, the English teacher taught reading comprehension by asking the students to discuss, read the text and then answer the question without asking the students to identify all the words in order that the students did not have a lot of vocabulary to comprehend the text especially narrative text. But, when the researcher conducted the researcher, she taught the students how to identify and group the words such verb, noun, adjective, and adverb. This step was very important for the students to make them master a lot of vocabulary because one of the important things to comprehend the text is vocabulary. Furthermore, through this step the students are able to comprehend the language features of narrative text. And then, when the English teacher asked the students to answer the comprehension question, most of the students could not answer the question because the English teacher did not know how to make the students have a lot of vocabulary to comprehend the text. While in this research, the researcher taught the students how to increase vocabulary i.e. by asking the students to list, group, and label the words related to the text. When the students list, group, and label the words, they have many vocabularies to comprehend the text and helps them to answer the question from the text.

A large vocabulary can help the students to express their ideas directly. Without knowledge of vocabulary mastery, the students felt confuse in comprehending reading text. Therefore, if the students had rich vocabulary they can comprehending reading text easier.

\section{CONCLUSION}

List-Group-Label Strategy has a significant effect to the students' ability in reading comprehension rather than the students who are not taught by using of List-Group-Label Strategy. Moreover, based on the result of computation of mean score of the test, it got that the students' mean score of pretest in control group was 61.17, while the students' mean score of posttest in control group was 68.00 , furthermore, the students' mean score of pretest in experimental group was 63.50, while the students' mean score of posttest in experimental group was 79.67, Lastly, based on the result of examining the hypothesis, it got tcount $=5.067$ and ttable $=2.002$. Because tcount $>$ ttable (5.067) $>$ (2.002), so Ha is accepted and Ho is rejected.

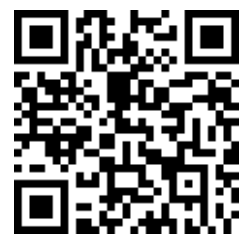

DOI PUBLIKASI https://doi.org/10.37010/int.v2i1 
It can be concluded that there is a significant effect of List-Group-Label Strategy on Students' Reading Comprehension.

\section{BIBLIOGRAPHY}

Andini, R.U. \& Ratmanida. (2019). Teaching Reading through "The Power Of Two" Strategy For Senior High School Students in Journal of English Language Teaching. 8(1), 33-41. Padang: English Language Teaching Study Program of FBS Universitas Negeri Padang.

Arikunto, S. (2006). Procedures of Research. PT. Asdi Mahasatya: Jakarta.

Ary et al. (2010). Introduction to Research in Education. Australia: Wadsworth Cengage Learning.

Bos, S.C. \& Vaugh, S. (2009). Strategies for Teaching Students with Learning and Behaviour Problems Seventh Edition. New Jersey: Pearson Education.

Brown, D.H. (2004). Language Assessment Principles and Classroom Practices. San Francisco: Pearson education, Inc.

Brown, Douglas. (2004). Teaching by principles: an interactive approach to language pedagogy. Englewood Cliffs, New Jersey: Prentice Hall Regents.

Bruner, Judy T. (2011). I Don't Get It: Helping Students Understand What They Read. United Kingdom.

Burns, C.P, Roe. D. P and Ross, B.E. (1991). Teaching Reading in today's Elementary Schools. Boston: Houghton Miffin Company.

Creswell W. J. (2009). Research Design: Qualitative, Quantitative, and Mixed Methods Approaches. USA: Univeristy of Nebraska-Lincoln.

Grabe, W. \& Stoller, F.L. (2012). Teaching and Researching Reading. New york: Routledge.

Institut Keguruan dan Ilmu Pendidikan Gunungsitoli. (2018). Pedoman Penulisan Skripsi. Gunungsitoli: Institut Keguruan dan Ilmu Pendidikan Gunungsitoli.

Johnson, A.P. (2008). Teaching Reading and Writing A Guidebookfor Tutoring and Remediating Students. United States of America: A Division of Rowman \& Littlefield Publishers, Inc.

Klinger, J.K, Vaughn. S, and Boardman A. (2007). Teaching Reading Comprehension to Students with Learning Difficulties. New York: A Division of Guilford Publications, Inc.

Macceca S. (2014). Reading Strategies for Science. Corinne Burton. Shell Education.

Nisa, R. et al. (2018). Students' Ability In Mastering Reading Comprehension. Getsempena English Education Journal (GEEJ). 5(1), 124-130. 
Nunan, D. (2003). Practical English Language Teaching. New York: McGrawHill/Comemporary

Park, H. (2000). When-question in second language acquisition. Second Language Research. 16(1), 44-76.

Rebecca, J. L. (2003). A Critical Handbook of Children's Literature. Massachuset: Pearson Education, Inc.

Santi, K. L. \& Reed, D. K. (2015). Improving Reading Comprehension of Middle and High School Students. New york : Springer International Publishing Switzerland.

Setiyadi, R. et al., (2019). Learning of Reading Comprehension through Reading Workshop in the Industry 4.0 in Journal Mimbar Sekolah Dasar. 6(2), 160-173. Cimahi: Primary School Teacher Education Study Program, IKIP Siliwangi.

Smith, F. (1982). Understanding Reading. 3rd Ed. New York: Holt, Rinehart, and Winston.

Stein, E. (2013). Comprehension Lessons for RTI Grades 3-5: Assessments, Intervention Lessons, and Management Tips to Help You Reach and Teach Tier 2 Students. New York: Scholastic Teaching Resources.

Sugiyono. (2010). Stastistika Untuk Penelitian. Bandung: CV. ALFABETA

Tiemey, R. J., Readence, J. E. \& Dishner, E. K. (1990). Reading strategies and practices: A compendium. Boston: Allyn and Bacon. 